\title{
Seaweed Growth Rate (Eucheuma cottonii) in Monoculture and Co-Culture Cultivation Systems in Coastal area of Pandawa Beach, Bali
}

\author{
Yesi Breanita $^{1 *}$, Ni Luh Watiniasih ${ }^{2}$, Ayu Putu Wiweka Krisna Dewi ${ }^{1}$ \\ ${ }^{1}$ Department of Aquatic Resources Management, Faculty of Marine and Fisheries, Udayana University \\ ${ }^{2}$ Department of Biology, Faculty of Mathematics and Natural Sciences, Udayana University \\ Jl. Kampus Unud Bukit Jimbaran, Kuta Selatan, Badung, Bali \\ *Corresponding author: yesibreanitaa@gmail.com
}

\begin{abstract}
Seaweed is one of Indonesia's fishery commodities with great potential to be cultivated, the condition of seaweed produced in Indonesia is not optimal yet. This can be seen from the low productivity of seaweed in Indonesia which is caused by the low growth rate. The growth rate of seaweed can be supported by proper planting techniques and cultivation methods. Seaweed farmers generally use planting techniques and traditional cultivation methods called the monoculture system, which is planting one type of plant in an area. As the cultivation systems developed, a new cultivation system was found that supports increased growth of seaweed, namely the co-cultivation. This system is sustainable and environmentally friendly which combines species from various trophic in one system. This research was conducted for 6 weeks from December 2019 to January 2020 in the coastal area of Pandawa Beach, Bali. The data was analysed in Completely Randomized design with three treatments and three replications. The monoculture cultivation system which contain $100 \mathrm{gr}$ of seaweed in a bag was treated as control and co-culture systems were added with 10 and 30 individuals of abalones. The results showed that the growth rate pattern as a measure of weight increased during the time of study. The weight of seaweed was highest in co-cultured treatment with 10 individual abalones. The highest specific growth rate of seaweed occurred in the co-culture system up to 4\%/day compared to the monoculture cultivation system only $3.4 \% /$ day.
\end{abstract}

Keywords: monoculture; co-culture; Eucheuma cottonii; abalone

\section{INTRODUCTION}

Seaweed is one of Indonesia's fishery commodities that has great potential for cultivation with relatively simple cultivation technology and small capital required. However, the condition of seaweed production in Indonesia is still far from optimum, as the production of Indonesian seaweed is still low. The low productivity of seaweed in Indonesia is thought caused by the low growth rate of seaweed [1].

The growth rate of seaweed can be supported by proper planting techniques and cultivation methods. Seaweed farmers generally use a traditional cultivation method called the monoculture system. The monoculture system is a cultivation system by planting one type of plant in one area, but it has a disadvantage that the plants are relatively susceptible to pests and diseases [2]. Increasing knowledge of the seaweed cultivation system, it has been found that co-culture cultivation system can increase growth of seaweed, in which this system combines species from different trophic in the same system, and is environmentally friendly [3].

Application of Eucheuma cottonii seaweed cultivation with a monoculture and co-culture integrated system with Haliotis squamata abalone in the coastal water of Pandawa beach was investigate with the hypothesis that co-cultured of seaweed with various abalone densities can increase the seaweed production. Seaweed has a role as a waste biofilter from feces and leftover feed that is not consumed by abalone and can be used as a source of nutrients for the growth of seaweed, but abalone is also consume seaweed [4]. The positive effects of seaweed as a bio-filter and the availability of nutrients by abalone on seaweed may increase the production of seaweed, therefore this study was important to be conducted.

\section{METHODS}

\section{Experimental set up}

This experiment was designed in Completely Randomized Design Method. The monoculture cultivation system experiment (treatment A) was carried out without abalone, whereas the co-culture system experiment was carried out with 2 treatments using 10 abalone (treatment B) and 30 abalone (treatment $\mathrm{C}$ ) with 3 repetitions for each treatment.

\section{Materials}

The materials used in this study were E. cottonni seaweed seeds, $H$. squamata abalone seeds, and water samples from Pandawa Beach. The tools used in the study consisted of tools for measuring water quality and 
measuring the growth of seaweed and abalone, such as refractometer (ATAGO), secchi disk (Mona Instrument), drifter buoy, $\mathrm{pH}$ meter (ATC), thermometer (TPM-10 Thermometer), DO meter (DO Smart Sensor AR8210), spectrophotometer (Visible Spectrophotometer 721 $3501020 \mathrm{~nm}$ ), digital scales (SF-400), plastic baskets, ropes, iron stakes, nets, meters, and stationery.

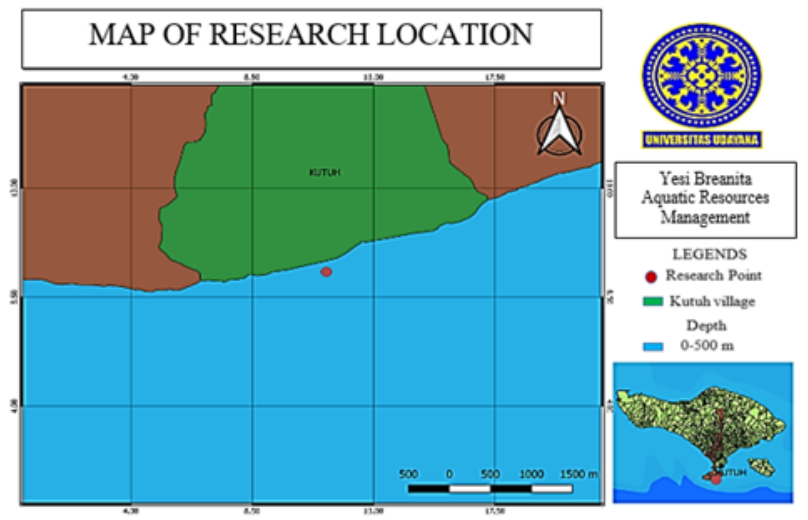

Figure 1. Map of Research Location

\section{Selection of seeds}

E. cottonii seaweed seeds used were obtained from Serangan Beach, Bali with the weight of 100 grams for each sample treatment. H. squamata abalone seeds used in the co-culture system obtained from the Center for Marine Cultivation Research and Extension, Gondol (BBRBLPP), with a shell length about $4 \mathrm{~cm}$ and a width of $3 \mathrm{~cm}$, Total of abalone seeds used in the co-culture system was 120 abalone seeds.

\section{Planting Stage}

Seaweed cultivation uses the off-bottom method where the monoculture system was used as a control, unintegrated with abalone, whereas in co-culture construction, seaweed cultivation was integrated with abalone. The rope used were 3 meters long. Ropes were stretched parallel, tied to two iron stakes embedded in the seabed. Range between the planting point of seaweed seeds and the planting point of other seaweed seeds in the rope is about $20 \mathrm{~cm}$. All treatments used 2 stretch ropes, each containing 5 seaweed planting seeds. The range between the seabed and the rope that used for planting seaweed was about $30 \mathrm{~cm}$. In the co-culture system, the abalone was placed and maintained in a plastic basket with a size of $43 \mathrm{~cm} \times 30 \mathrm{~cm} \times 15 \mathrm{~cm}$.

\section{Water Quality Measurement}

Data retrieval of water quality was carried out once a week during the study. The physical and chemical parameters measured are temperature, salinity, water brightness, ocean currents, dissolved oxygen, acidity, nitrate and phosphate. Measurement of temperature, salinity, water brightness, ocean currents, DO, and acidity were measured in situ and the nitrate and phosphate were carried out to the Laboratory of Aquatic Resources Management, Udayana University for the analysis.

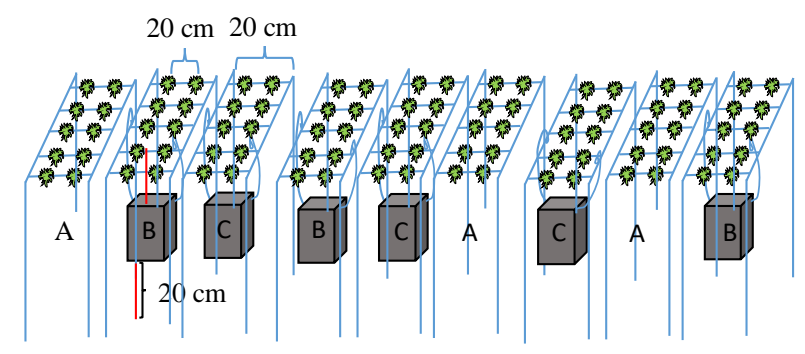

Figure 2. Illustration of Seaweed Cultivation Experiment Design

\section{Data Analysis}

The data was analyzed in One Way Anova test followed by Duncan's advanced test using if the result found differences among treatments, in the Statistical Package for The Social Sciences (SPSS) software with a confidence level of $95 \%(\alpha=0.05)$. From the value of the growth rate, it can be seen that the cultivation system can increase the productivity of more effective seaweed cultivation. The specific growth rate was calculated using a formula [5] described below:

$S G R=\frac{\operatorname{LnWT}-\text { LnWO }}{t} \times 100 \%$

Noted: SGR is specific growth rate of E. cottonii (\%/day), $\mathrm{Wt}$ is the final weight of the seaweed (gr), Wo is the beginning weight of seaweed (gr), $\mathrm{t}$ is time.

The survival rate of abalone $H$. squamata [6] was calculated using a formula describe below:

$\mathrm{SR}=\frac{N t}{N o} \chi 100 \%$

Noted: SR is survival rate of abalone $H$. squamata, Nt is total abalones at the end, No is total abalone at the beginning.

\section{RESULT AND DISCUSSION}

\section{Seaweed Growth}

The increase weight of seaweed each week tends to have the same growth pattern in each treatment. In treatment $\mathrm{A}$, the weight of seaweed increased in the range of 24-86 grams/week from the first through the $6^{\text {th }}$ week of treatments. The weight of seaweed in treatment B increased in the range of 27-88 grams/week, from the first week through the $6^{\text {th }}$ week, while in treatment $C$, the weight of seaweed increased between 32-122 grams/week. The increase weight of the three treatments in the first week through the $3^{\text {rd }}$ week were lower than that of in $4^{\text {th }}$ week to $6^{\text {th }}$ week. This is suspected due to the first week through the $3^{\text {rd }}$, seaweed have first phase called adaptation 
phase (lag phase) where there is an adjustment of the cell to the new environment. The study by Eismaputeri et al. [7], found that the first week and the $3^{\text {rd }}$ week were the phase lag in which the growth of seaweed is slow because cells were adapted physiologically, causing slow metabolism for the growth.

The weight of the three treatments from the $4^{\text {th }}$ week through $5^{\text {th }}$ week continues to increase. This is suspected that seaweed due to the $4^{\text {th }}$ week through $5^{\text {th }}$ week goes through the adaptation phase well and enters the exponential phase, which at this time the seaweed is in optimal conditions for growth, also the absorption of nutrients in the waters very well, along that the increase weight of seaweed occurs quickly and optimal. The study by Richmond [8], the protein content in cells at an exponential phase is very high, so that the macro algae conditions are in optimal conditions. In this phase, macro algae require more nutrients and are more sensitive to environmental conditions.

The increase weight of $6^{\text {th }}$ week have acceleration decrease which was not too significant between the three treatments when compared to the previous week This is suspected that of the $6^{\text {th }}$ week, the seaweed into the stationary phase, where seaweed has passed the exponential phase well, seen from the growing number of talus which is getting bigger, lush, and heaped each other between the thallus, that there is competition for nutrient absorption and sunlight, effect in the rate of seaweed weight become slowing down and decreasing. Another factor that slows growth is the number of macro epiphytes such as Ulva sp. and Hypnea sp. and pieces of seagrass that get stuck to the protective nets and ropes, causing high competition between the talus and macro epiphytes and seagrass pieces for nutrient absorption. The study by Sabarno et al. [9], along with the increasing age of maintenance of seaweed causing competition in obtaining nutrients and absorption of sunlight as food intake, effect in the rate of seaweed weight become slowing down and decreasing.

The growth rate of seaweed in monoculture systems is lower than in co-culture systems. This is suspected due to monoculture cultivation system of seaweed is cultivated independently without being integrated with other trophic uses abalone, causing the absorption of nutrients is only small and limited compared to the co-culture system. The higher growth in the co-culture cultivation system is due to seaweed acts as a bio-filter that can take advantage of waste products in the form of feces and food scraps from abalone in the form of $\mathrm{CO} \neg 2$, inorganic nutrients in the form of ammonium (NH4), and phosphate which will be used in the photosynthesis process. In the presence of organic material and supports the process of photosynthesis, it will support the growth process of seaweed to be even greater. Study by Sukti et al [9], seaweed as a bio-filter can also reduce excess nutrients which is not utilized properly in the water that the aquatic ecosystem remains balanced.

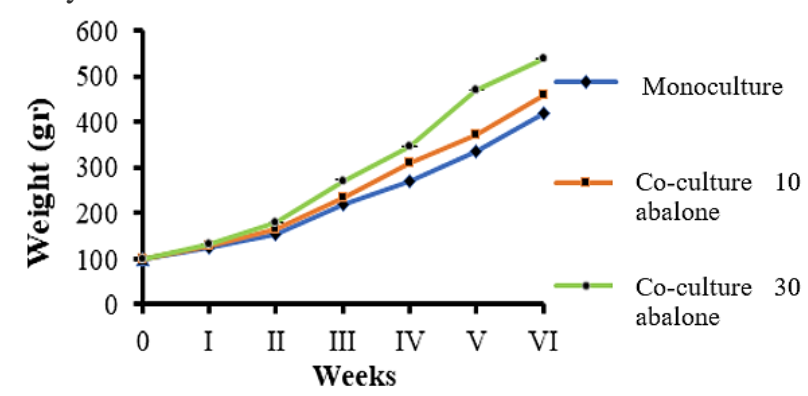

Figure 3. The Growth Pattern of Seaweed between Treatments

\section{Specific Growth Rate (SGR)}

The increase weight of the seaweed planted for 42 days resulted from a specific growth rate (SGR) in treatment A was $3.42 \% /$ day, treatment B was 3.63\%/day, and treatment $\mathrm{C}$ was $4 \%$ /day. The percentage of SGR in treatments A, B, and $\mathrm{C}$ increased with a value of SGR above $3 \%$. Study by Sulistiani and AY Samsul [11], that a seaweed cultivation activity is categorized as good and profitable if daily growth rate above $3 \%$. This is suspected that parameters of the quality of Pandawa coastal waters support for seaweed cultivation activities. Study by Peruzzi and Oliveira [12], that seaweed usually has a high growth rate when are in a nutrient-rich environment to fulfil the growth supply. Study by Yuniarsih et al. [13], that the ability of seaweed to absorb nitrate and phosphate nutrients can be used as an indicator the development of seaweed cultivation based on co-culture support of the marine culture which is oriented towards increasing production (biomass).

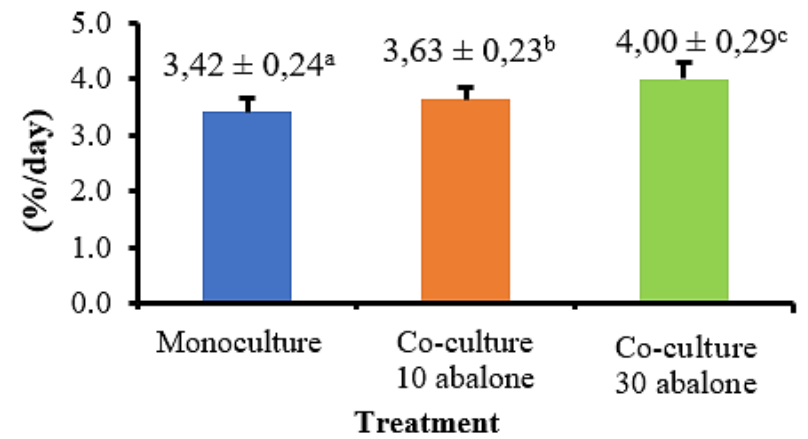

Figure 4. Seaweed Growth Rate between Treatments

The One Way Anova test results on the specific growth of seaweed between treatments showed that the significant value was 0.001 ( $\mathrm{p} \leq 0.05)$, which means that different treatments which are monoculture and co-culture causes a difference in the growth rate of seaweed.

\section{Survival Rate of Abalone H. Squamata}

The highest survival value of $H$. squamata abalone occurred in treatment $\mathrm{C}$ using 30 abalone with an average survival rate of $96.7 \%$, while the survival rate in treatment 
B using 10 abalone is lower with an average survival rate of $80 \%$. The decrease in the survival rate of $H$. squamata abalone during the research was thought to fluctuations in water conditions. There was a significant decrease in the DO value of the waters at $4^{\text {th }}$ week, also value of the degree of acidity $(\mathrm{pH})$ decrease of the waters outside of the optimum range of abalone life causes abalones stress also death. Study by Susanto et al [14] states that abalone can be easily stressed to cause death due to the influence of environmental fluctuations such as temperature, oxygen content, and ammonia.

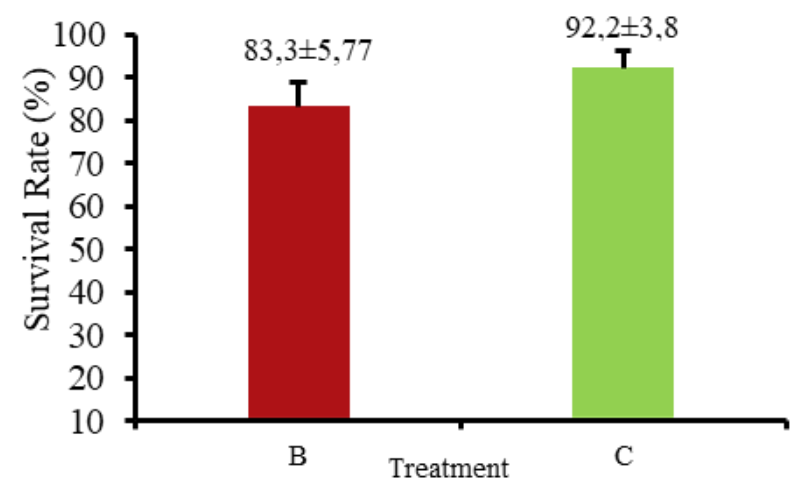

Figure 6. Survival Rate of Abalone H. Squamata.

\section{Water Quality Parameter}

The measured water quality parameters are at the optimal level for seaweed cultivation also for the survival of abalone, because based on the measurement results, water quality in Pandawa's coastal water according to the standard of water quality feasibility.

\begin{tabular}{|c|c|c|c|c|c|c|c|c|c|}
\hline \multirow{2}{*}{ Parameter } & \multicolumn{7}{|c|}{ Measurement results per week } & \multirow{2}{*}{ Averages } & \multirow{2}{*}{$\begin{array}{c}\text { Standart } \\
\text { Deviation }\end{array}$} \\
\hline & 0 & 1 & 2 & 3 & 4 & 5 & 6 & & \\
\hline $\begin{array}{c}\text { Temperature } \\
\left({ }^{\circ} \mathrm{C}\right)\end{array}$ & 29 & 31 & 30 & 30 & 29 & 28 & 29 & 29,28 & 1,11 \\
\hline Depth $(\mathrm{cm})$ & 66 & 158 & 80 & 152 & 62 & 156 & 128 & 111,71 & 46,93 \\
\hline $\begin{array}{l}\text { Ocean current } \\
(\mathrm{m} / \mathrm{s})\end{array}$ & 0.08 & 0.17 & 0.1 & 0.16 & 0.08 & 0.17 & 0.13 & 0,11 & 0,05 \\
\hline $\begin{array}{c}\text { Disolved } \\
\text { Oxygen (ppm) }\end{array}$ & 5.5 & 7.06 & 6.9 & 8.5 & 4.4 & 5.1 & 4.06 & 5,93 & 1,6 \\
\hline Salinity (ppt) & 29.5 & 31.3 & 30.3 & 30 & 30.6 & 28.4 & 31 & 30,15 & 0,98 \\
\hline Acidity & 7.3 & 7.4 & 7 & 7.2 & 6.8 & 7 & 7.7 & 7,2 & 0,26 \\
\hline Nitrate $(\mathrm{mg} / \mathrm{L})$ & & 1.37 & & 2.15 & & & 1.96 & 1,82 & 0,34 \\
\hline $\begin{array}{c}\text { Phosphate } \\
\text { (mg/L) }\end{array}$ & & 0.10 & & 0.22 & & & 1.25 & 0,52 & 0,63 \\
\hline
\end{tabular}

Table 1. Water Quality Parameters

\section{CONCLUSION}

Monoculture and co-culture methods have different effects on the growth rate of seaweed. The highest growth occurred in seaweed with a co-culture system of up to $4 \%$ when compared to seaweed cultivated in monoculture which is only $3.4 \%$ with the survival rate of $H$. squamata abalone when integrated with $E$. cottonii have a high survival rate of around 80-96.7\%.

\section{ACKNOWLEDGMENT}

We would like to thank the management of Pandawa Beach and the research team for all contributions to this research.

\section{REFERENCES}

[1] Nurrahmawan, M. E., \& Jadid, N. 2017. Growth Rate of Seaweed Explants (Gracilaria verrucosa (Hudson) Papenfuss) in vitro. Jurnal Sains dan Seni ITS, 6(2), E5-E8.

[2] Gultom, R. C., Dirgayusa, I. G. N. P., \& Pusphita, N. L. P. R. 2019. Comparison of the Growth Rate of Seaweed (Eucheuma cottonii) Using Co-Culture and Monoculture Cultivation Systems in Geger Beach Waters, Nusa Dua. Bali. Journal of Marine Research and Technology, 2(1), 8-16.

[3] Barrington, K., Chopin, T., \& Robinson, S. 2009. Integrated Multi-Trophic Aquaculture (IMTA) In Marine Temperate Waters. Integrated mariculture: a global review. FAO Fisheries and Aquaculture Technical Paper, No. 529, 7-46

[4] Troell, M., Joyce, A., Chopin, T., Neoru, A, Bushmann, A.H., \& Fang, J-G. 2009. Ecological engineering in aquaculture-potential for integrated multitrophic aquaculture (IMTA) in marine offshore systems. Aquaculture, 297, 1-9.

[5] Syahlun, Rahman, A., Ruslaini, 2013. Seaweed growth test (Kappaphycus alvarezii) brown strain with verticulture method. Jurnal Mina Laut Indonesia. 1(1). 122-132.

[6] Yustianti, Y., Ibrahim, M.N., \& Ruslaini, R. 2013. Growth and survival of vaname shrimp larvae (Litopenaeus vannamei) through substitution of fish meal with chicken intestine flour. Jurnal Mina Laut Indonesia, 1(1), 93-103.

[7] Eismaputeri, M. K. 2013. Effect of Photoperiod and Salinity on the Growth and Chlorophyll A from Sargassum Sp. [Doctoral dissertation], UNIVERSITAS AIRLANGGA.

[8] Richmond, A. 2004. Biological principles of mass cultivation. Handbook of microalga culture: Biotechnology and applied phycology, 125-177.

[9] Sabarno, A., Patadjai, R. S., Rahman, A., \& Kurnia, A. 2019. The Effect of Different Seed Weight on the Growth and Production of Seaweed Gracilaria verrucosa using long line Method in the Brackish Water Pond. Jurnal Media Akuatika, 3(2).

[10] Sukti, A. N., Effendy, I. J., \& Sarita, A. H. 2016. The Ratio of Growth Rate and Survival Rate Population of Abalone Reared with Sponge and Seaweed. Media Akuatika: Jurnal Ilmiah Jurusan Budidaya Perairan, 1(1), 11-18.

[11] Sulistiani, E., \& Samsul, A. Y. 2014. Kultur jaringan rumput laut kotoni (Kappaphycus alvarezii). Seameo Biotrop. Bogor.

[12] Oliveira, V. P., Freire, F. A. M., \& Soriano, E. M. (2012). Influence of depth on the growth of the seaweed Gracilaria birdiae (Rhodophyta) in a shrimp pond. Braz. J. Aquat. Sci. Technol, 16(1), 33-39 
[13] Yuniarsih, E., Nirmala, K., \& Radiarta, I. N. 2014 Nitrogen and phosphorus absorption levels on the seaweed aquaculture based on IMTA (Integrated multi-trophic aquaculture) system in Gerupuk Bay, Central Lombok, West Nusa Tenggara. Jurnal Riset Akuakultur, 9(3), 487-500 